\title{
Belgeo
}

Revue belge de géographie

$1 \mid 2019$

Miscellaneous

\section{The reception of asylum seekers in urban areas: the case of the city of Milan}

L'accueil des demandeurs d'asile dans les espaces urbains : le cas de la ville de Milan

\section{Valerio Bini and Giuseppe Gambazza}

\section{(2) OpenEdition}

\section{Journals}

Electronic version

URL: http://journals.openedition.org/belgeo/35559

DOI: 10.4000/belgeo.35559

ISSN: 2294-9135

Publisher:

National Committee of Geography of Belgium, Société Royale Belge de Géographie

\section{Electronic reference}

Valerio Bini and Giuseppe Gambazza, «The reception of asylum seekers in urban areas: the case of the city of Milan », Belgeo [Online], 1 | 2019, Online since 06 January 2020, connection on 07 July 2020. URL : http://journals.openedition.org/belgeo/35559; DOI : https://doi.org/10.4000/belgeo. 35559

This text was automatically generated on 7 July 2020 .

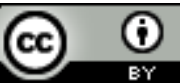

Belgeo est mis à disposition selon les termes de la licence Creative Commons Attribution 4.0 International. 


\title{
The reception of asylum seekers in urban areas: the case of the city of Milan
}

\author{
L'accueil des demandeurs d'asile dans les espaces urbains : le cas de la ville de
} Milan

Valerio Bini and Giuseppe Gambazza

\section{Introduction}

1 The paper deals with the reception system for asylum seekers in Italy, specifically focusing on the case of the city of Milan in the period 2013-18. The period is defined by the intensification of the so-called "Syrian refugees crisis" (2013) 1 and the official assignment of Giuseppe Conte's government (2018-2019) (June 2018), which has significantly changed the ongoing policies.

2 The research addresses the subject of the reception of asylum seekers from a geographical perspective. Firstly, it focuses on the multi-scalar interaction between international community, national governments, local communities and civil society (Badie et al., 2008). Secondly, it analyzes the effect of the reception system in urban areas.

3 The paper consists of seven sections. Following this introduction, we will present the theoretical framework, the methodology and the legal background. Afterwards we will illustrate the "twin-track" approach developed by the municipality, where local structures grow alongside the national ones. In the sixth section, we will analyze the placement of the centers and their relationship with the neighborhood, with specific reference to the case of the area at Milan's main railway station, Milano Centrale. This is, in fact, the urban sector with the highest concentration of reception centers. In the conclusion, we will sum up the relations between the case study and the theoretical framework defined in the introduction. 


\section{Theoretical framework} the urban scale. In this sense the theoretical framework draws on the research around the role of the State in the migration policymaking (Sayad, 1999), translated in a context of crisis of the traditional nation-state (Badie, 1995) and the emergence of cities as new political players (Sassen, 2001).

In the last twenty years, the research on migration policies has started to stress the specific role played by municipalities, pleading for a new approach that gets rid of the "methodological nationalism" in order to build a "theory of locality in Migration Studies" (Glick Schiller and Çağlar, 2009). Most of this literature addresses the issue of migration in general, often focusing on the role of local policies in the integration of immigrants (Caponio and Borkert, 2010). Here, we apply this theoretical framework to a narrower subject: the reception system of asylum seekers, highlighting the agency of cities within the political framework defined by the State.

6 The case of Milan is meaningful because it shows how the dialectical tension between the State and the City is not limited to the biggest global cities but also lower ranked centers. Thus, beside the practical observations on the strategic role played by local authorities in the implementation of national and supra-national integration policies, here we highlight a process of rescaling (Brenner, 2004; Swyngedouw, 2004) through which local authorities follow or challenge the power of the national government.

With this regard, Scholten (2013) distinguishes four ideal type configurations of relations between government levels: centralist (top-down), localist (bottom-up), multilevel, and decoupled.

8 The centralist ideal type involves a top-down relationship between the different levels of government, in order to ensure that policy implementation at the local level follows central rules and reflects the central policy frame.

9 In the second type, local governments formulate policies, respond to local policy agendas, and exchange knowledge and information horizontally with other local governments. This localist type may lead to greater policy divergence between the national and the local level.

The third ideal type, the multilevel governance, is founded on the positive interaction between the various levels of government without clear dominance of one level.

The fourth type, the decoupled governance, is characterized by the absence of any meaningful policy coordination between levels. This type can lead to policy conflicts between government levels.

12 The analysis of the urban policies on asylum seekers defines the second axis of our research, concerning the distribution of immigrants and the socio-spatial segregation within the urban fabric, a topic with a long theoretical history. At a first stage, with the researches made by Chicago School, socio-economic variables were assumed as a determining factor in the construction of the processes of segregation. Later, a new approach emerged introducing a multi-scalar analysis on the determinants of the spatial segregation (Massey and Denton, 1988; Reardon and O'Sullivan, 2004; Brown and Chung, 2006). Finally, more recent research has stressed a wider range of factors that influence the processes of concentration and social-spatial segregation. This current 
includes the studies on the cultural distance between the immigrant population and the host society (Schnell et al., 2015), on the role of the public and private real estate market (Smith, 2011) and on the importance of institutions in determining segregation areas (Musterd and Ostendorf, 2013). The present research - focused on the role of the municipal institutions in organizing asylum seeker and refugee reception - fits in the latter subgroup.

\section{Methodology}

The information and data presented come from official documents produced by local and national institutions (national statistics and reports on migration for the national scale; reception centers census for the urban scale) and from 15 semi-structured interviews with relevant actors of the local reception system.

Five interviews were directed to institutional subjects: members of the prefecture, employees of the municipality and the Director of the national Protection System for Asylum Seekers and Refugees (SPRAR - Sistema di Protezione per Richiedenti Asilo e Rifugiati ${ }^{2}$ ). The main objective of the interviews was to verify the operationality of the popular notion of the "Milan model" with reference to a specific welcoming system, more open and efficient compared to the national average.

The rest of the people interviewed were part of the civil society, either employees of non-profit organizations in charge of reception centers, or members of foundations specialized in migration issues. These meetings were aimed at understanding how the reception system works and which kind of local governance (centralist, localist, multilevel or decoupled) is implemented by the "Milan Model". All the interviews were conducted in the period from July 2018 to August 2019.

\section{The context: Europe, Italy, Milan}

The legal framework of the Italian reception system for asylum seekers is defined by the Geneva Convention and by the European Regulation on International Protection (Dublin III $^{3}$ ). Since 2007, following the Lisbon Treaty, the European Union has envisaged the necessity of a common strategy on migrations. In 2008, with the European Pact on Migration and Asylum, the European states set the objective of "building a Europe of Asylum". Moreover, the European Union has encouraged the development of a migration policy in urban areas: with the Milan Declaration (2007), for instance, the European Commission has officially acknowledged the role of cities within this topic.

In fact, in spite of all this multi-scalar debate, the national scale still dominates the asylum sector (Wihtol de Wenden, 2017) and the political conflict of refugee management is becoming one of the major challenges for the European Union or, as put by Etienne Balibar, the topic is defining the very "end of Europe" (Balibar, 2016). In fact, Dublin III regulation - stating that "the first Member State in which the application for international protection was lodged shall be responsible for examining it" (art. 3) - and the recent limits on the Schengen treaty implemented by many European countries, put national states in the foreground, casting dark shadows on the idea of a European policy on asylum seekers and on the positive role of cities within the process. 
18 As a consequence of this lack of cooperation, tension between Italy and the EU and other European states has grown: in fact, Italy is the major arrival point for asylum seekers, even though many of them are directed to other European countries that are hindering immigration.

19 The Italian protection system used to be structured in two sectors: international protection (political asylum and subsidiary protection) and humanitarian protection ${ }^{4}$ (for those who are not eligible for international protection). The relevance of these forms of protection transcended the protection sector itself, since in the period considered in this paper they have become a primary way to obtain a permit to stay in Italy: out of the 226,934 permits issued in 2017, more than one third (38.5\%) were justified by international or humanitarian protection, and only a small minority (4.6\%) were work permits. Ten years ago the proportion was the opposite $(150,098$ work permits, 9,971 protection permits, out of a total of 267,600 permits issued in 2008) ${ }^{5}$.

This inversion in the origins of the permits - produced by a political strategy that eliminated the ordinary access to work for migrants - is central in the understanding of the recent change in the Italian reception system. The creation of a mass of people asking for protection in the absence of an adequate system for examining the demands has produced huge delays in the procedures, jeopardizing the reception system. According to the $\mathrm{UNHCR}^{6}$, in December 2017 the total number of refugees in Italy was 167,335 , and the pending cases were 186,648.

21 Italy is characterized by a double-track reception system: an ordinary and an extraordinary one.

The origins of the ordinary system can be traced back to the "Piano Nazionale di Asilo" (National Asylum Plan) (1999-2001), when a first attempt was made to create a reception network with the involvement of local communities. In 2001, the Ministry of Interior, ANCI (the Associazione Nazionale Comuni Italiani - National Association of Italian Municipalities) and the UNHCR signed a memorandum of understanding establishing the first public reception network in Italy, which was institutionalized by Law 89/2002 under the name of "SPRAR" (Protection System for Asylum Seekers and Refugees) (Semprebon, Pelacani, 2020).

Beside this system, in 2011 the government has envisaged the development of a parallel emergency system of reception temporary structures, the so-called CAS (Centri di Accoglienza Straordinaria - Centers of Extraordinary Reception), in order to cope with the increasing number of arrivals by sea that followed the outbreak of the Arab Spring. Theoretically, the current welcoming system in Italy is structured in two stages: the first reception implemented in collective centers and the second reception that should foster the integration of the refugees and the asylum seekers.

Upon migrants' arrival, medical assistance is provided and identification procedures are carried out in hotspots or at the ports of arrival (where they should remain for 2 days). Afterwards the asylum seekers are taken to collective governmental reception centers (regional hubs). During the examination procedure (that should take maximum up to 6 months), asylum seekers should be taken care of by the second reception system (SPRAR), based on small decentralized structures that should foster the integration of refugees and asylum seekers. When places are insufficient, migrants are distributed across centers of extraordinary reception (CAS), located throughout the country ${ }^{7}$. 

solution, aimed to integrate the ordinary system in emergency situations ${ }^{8}$, in practice they have become the normal way to accommodate migrants ${ }^{9}$, and their stay in such structures frequently exceeds a year (the average time to process the demands was 307 days) (ANCI et al., 2017). In January 2017, in fact, the total number of migrants hosted in reception structures was $175,550.136,978$ (78\%) of which were assigned to CASs, 23,822 $(13.6 \%)$ to the SPRAR system and the rest to first reception structures ${ }^{10}$. Is subsidized by the National Fund for Asylum Policies and Services (funded in turn by the EU Asylum, Migration and Integration Fund). with 649 projects (Baldoni et al, 2018). The financial resources come both from the government and the local authorities, but the management of the centers is under the control of the single municipalities. The SPRAR projects are destined to people who are waiting for protection and to those that have obtained the status of refugee, so their purpose is not simply to give a temporary shelter to people waiting for the outcome of their demands but to support their integration in the social fabric. In order to ease this integration, these structures are usually smaller than CASs, often hosting families or small groups of people in apartments made available by the municipalities.

This decentralized strategy is obviously labour-intensive and so the projects usually involve a number of social organizations that work in partnership with local authorities.

33 A general problem of this system is that the number of places made available by the SPRAR program is by far smaller than what is needed and so the system structurally produces large groups of people holding the refugee status but not receiving any support.

Milan is an important case study because the city attracts migrants from other parts of Italy, either to stay or as stop-over towards other destinations in Europe, so it has developed specific needs in terms of reception system. 


\section{The protection system of Milan}

The protection system of the city embodies a multiplicity of actors and structures which are managed, on the one hand by the local authority and on the other by the prefectural system (which is a direct expression of the centralized power).

The municipality of Milan, in fact, has amended the national approach to the immigration issue, giving it a more nuanced and flexible implementation, as evidenced by the presence of a mixed governance, in which State and local authorities are involved with welcoming structures management.

This cooperation was one of the requirements for developing the so-called "Milan Model", a system for the reception of relevant flows of asylum seekers, which includes those coming from Hotspot Centers (the structures assigned to the initial reception of migrants) as well as other Regional Hubs. We can follow the emergence of this system along the years, from 2013 up to 2018.

\section{At the beginning of the Milan "twin-track" model: the Syrian "crisis"}

As long as the EU rules have allowed migrants to overcome the internal borders in order to reach bordering countries, Milan was mainly considered by migrants only a temporary step in the journey from the Mediterranean coasts to the northern and central cities of Europe. Despite its distance from the sea, the city has always attracted wide flows of immigrants thanks to its facilities and its strategic position along two major Trans-European corridors (Mediterranean and Rhine-Alpine).

The "Milan Model" was born in 2013 as a consequence of the so-called "Syrian Emergency", to handle the arrival of people escaping from the civil war and looking for an accommodation in the city's reception centers ${ }^{12}$. The "Syrian Emergency" was undertaken by the contribution of civil society and local authorities: at the time, in fact, a large group of volunteers provided the first assistance for immigrants scattered around Milano Centrale railway station. as not to be subjected to the dictates of the Dublin Regulation, which would have "confined" them to the Italian national territory. The local administration was consequently induced to address the problem appointing the "Syrian Emergency" as a social issue and not just as an immigration one, which would have been in charge of the national government. Through this shortcut the local authority succeeded in including the identification in its own list of competences, establishing a legal instrument to help people carry out their migratory project within a framework of legality and security.

With the endorsement of the Ministry of the Interior, it was therefore introduced the new status of "Transitante"13 , referring to a legal figure who was allowed to stay in Italy for a short period of time, with no obligation to immediately ask for international protection. In other words, the Transitanti were given seven days to decide whether to apply for asylum or to continue their journey crossing the Italian borders. In this way, the local authorities finally legitimized the immigrants from an institutional point of view, providing assistance to those who needed it.

From a socio-territorial point of view, the main effect of this geo-political process on the Milan protection system was the institution of a diurnal center (Via Tonale, next to 
Milano Centrale station) run by the non-profit Fondazione Arca, which would have eventually moved to the nearby Via Sammartini, extending its activities to work also nights.

It is estimated that, from 2013 to 2017, immigrants accommodated in the structures of in the Milanese territory were around 125,500, many of which stayed in the Sammartini Hub for a few days (three on average) ${ }^{14}$. The center, which hosted approximately 700 guests per night, played a dual role: humanitarian and institutional. On the one hand, its purposes were to supervise the neighborhood, in order to bring immigrants to the $\mathrm{Hub}$ (the "Hub Mobile Service") and give them a temporary resting place. On the other, the center dealt with the identification of migrants and therefore their inclusion in the institutional circuit.

\section{The "Milan Model" today}

With the reintroduction of border controls by neighbouring countries in $2016^{15}$, the Ministry of Internal Affairs has gradually abolished the figure of the Transitante, with a consequent significant increase in the number of asylum seekers. Milan was suddenly confronted with the problem of overcrowding in the Sammartini Center ${ }^{16}$, which pushed people out onto the streets, creating discontent and complaints among the local population. Despite these changes, the city did not give up on developing its role as one of the major players in the national system of migrant reception and continued to be in charge of the first recognition function: the Municipality of Milan, in fact, appointed their employees responsible for the identification of Asylum Seekers, taking this function away from the Sammartini Center volunteers that had carried it out in the past.

Furthermore, tasks, roles and responsibilities of the ordinary and extraordinary structures of reception (SPRARs and CASs) were progressively redefined. As some interviews show, in Milan they ceased to carry out the same duties (the reception of both asylum seekers and refugees), undertaking specific activities: the extraordinary reception facilities mainly welcomed asylum seekers, local SPRARs hosted refugees, thus by-passing the national system that formally supervises the ordinary system.

From that period onwards, Milan governance has also been gradually structured through multi-level relations between local and national institutions, which created a sort of "third way" of reception for refugees and asylum seekers, between the ordinary and the extraordinary systems (SPRARs and CASs): the so-called "Municipal CASs", hybrid structures managed by the municipality but funded by the Prefecture. For the first time in Italy a municipality was directly involved in the implementation of the necessary measures to establish additional extraordinary centers, in governing the flows of asylum seekers. These new structures received people from a "municipal" channel ${ }^{17}$, and generally provided better services than the "normal" extraordinary centers in terms of social integration (language classes, contacts with social and economic networks).

This initiative by the local government produced the "twin-track" (municipal/national) reception system that is one of the characteristics of the "Milan model". Nevertheless, this model could not work without another crucial feature of the social structure of the city: the role played by the third sector. 


\section{The role of third sector in the protection system} concerns the significant differences between the governance practices carried out in the prefectural and municipal protection systems. The above mentioned "twin-track" approach suffers from the lack of a pluralistic and shared strong central coordination, thus leading to critical issues not easily solved. Nevertheless, while the strengthening of this network has contributed to respond to 
the increasing demand for hospitality, it has certainly produced distorted effects, which have yet to find a satisfactory solution.

This is connected with the progressive loss of importance of the SPRAR program which, once the Syrian crisis was over, ceased to perform its privileged function of asylum seeker and refugee reception, dealing mainly with beneficiaries of international protection. This re-organization limits the SPRAR system to those who drop out from CAS when receiving the status of refugee. In this way, the hierarchy of the Italian reception system is modified in order to identify CAS as the privileged centers of second reception, "moving backwards" SPRAR (and their relative integration strategies) to the lower status.

Moreover, the above-mentioned disproportion between extraordinary and ordinary reception centers indicates the persistence of a vision of reception as an emergency. A vision aimed at delaying structural solutions to the issue. In this case we can see that despite the work to improve the reception system on a local scale the Municipality of Milan has not been able to influence the national reception policies, thus suffering from the imbalances created by this short-sighted approach to the issue. Within the city, for example, an 8 to 1 ratio between the hospitality of the two protection systems produces a number of socio-political problems concerning the management of refugees, who are forced to leave CAS, even without an assigned SPRAR place.

For this reason, they often seek refuge in shelters for homeless, together with those who have left the SPRAR system without having succeeded in taking part in a profitable integration project.

In other words, the protection system fails in accompanying asylum seekers throughout their integration path and requires the further intervention of welfare agencies. This is particularly evident during winter, when many refugees find hospitality within the so-called "Piano Freddo", a municipal service created to offer protection to the homeless.

\section{The spatial segregation in the reception system}

A further difference between CAS and SPRAR reception systems concerns the different (and partly incompatible) logics that regulate the spatial distribution of the centers.

61 Firstly, the analysis shows how CAS organizes and manages a reception process, channeling flows of people as well as tangible and intangible assets towards large structures. According to this, the CASs in Milan have hosted asylum seekers in sizable structures, each of them welcoming about 20 guests on average.

Secondly, the SPRAR system follows an opposite logic, based on the concentration of goods and people in smaller spaces, which accommodate 17 people on average. Another declared objective of SPRARs is to plan an integration system for asylum seekers and refugees, organized into small-medium structures, evenly distributed over the territory. However, despite these typological differences between the reception systems, all the centers for asylum seekers and refugees (both CAS and SPRAR structures) are gathered in limited portions of the city. This concentration produces a juxtaposition between areas with high density of centers and areas with low or no density. 
Figure 1. Map of Milan CAS and SPRAR centers in 2017.

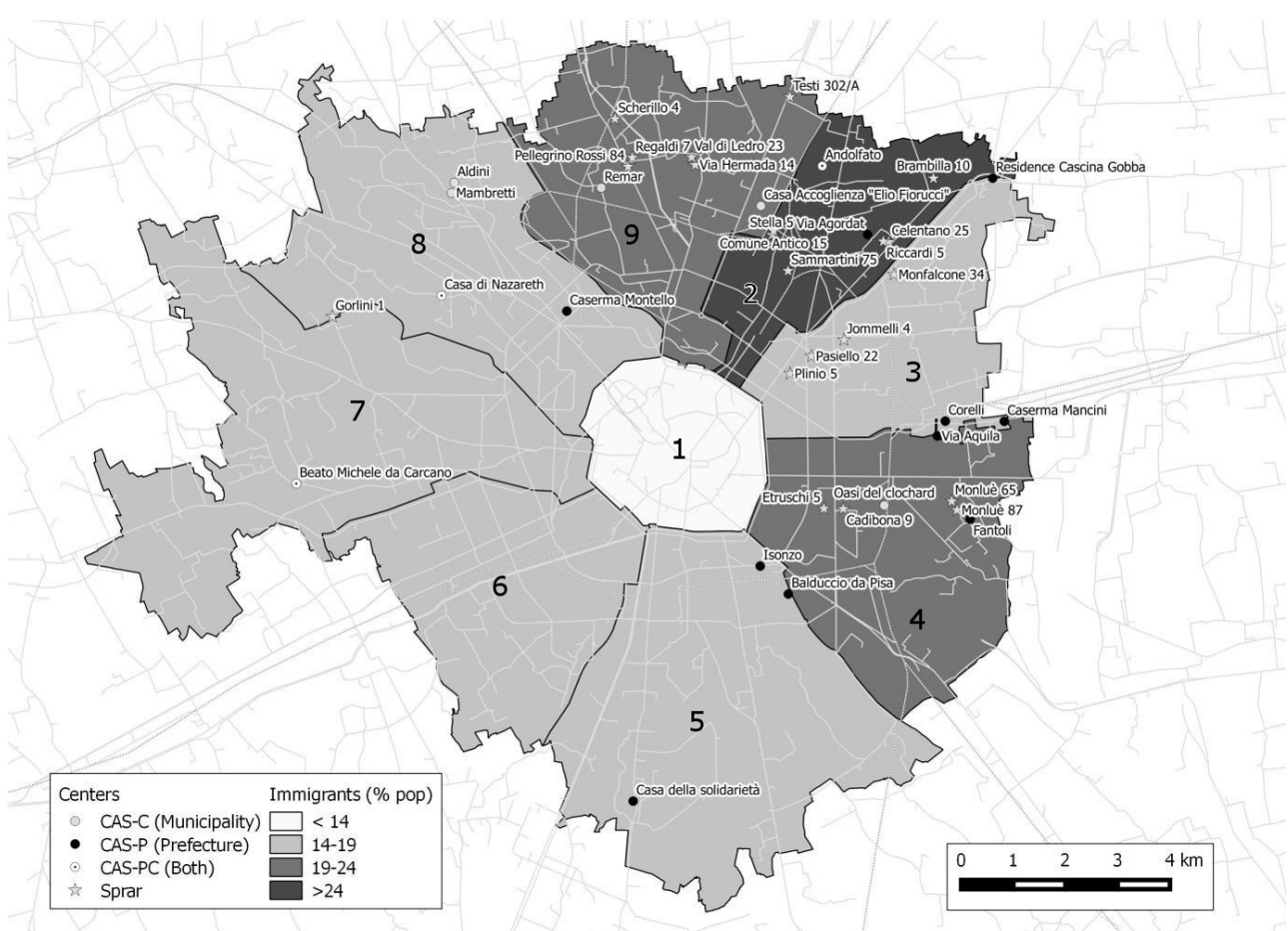

Source: Bini, Gambazza, 2019. Elaboration on the basis of interviews with officials of the Municipality of Milan (2018).

63 As the map shows, there is a greater concentration in the northeast quadrant of the city, a zone which has been involved by the migratory phenomenon for a long time and with a high percentage of immigrants.

Each of the nine districts of Milan shows a direct connection between its overall immigration rate and the density of SPRAR and CAS centers. Most of them, in fact, are settled within the boundaries of districts 2 and 9, which present the highest immigration rates, while the areas with lower levels of immigration host the lowest number of centers: this is the case of the "old town", a district with a limited number of immigrants and completely free from reception centers.

Table 1. Immigration rates and protection centers in the nine districts of Milan.

\begin{tabular}{|l|l|l|l|l|}
\hline Districts & Total Residents & Immigrants & \% Immigrants & No. of Protection centers \\
\hline District 1 & 97,403 & 11,797 & 12.1 & - \\
\hline District 2 & 159,134 & 45,862 & 28.8 & 8 \\
\hline District 3 & 142,939 & 21,332 & 14.9 & 6 \\
\hline District 4 & 159,750 & 30,540 & 19.1 & 7 \\
\hline District 5 & 124,903 & 21,840 & 17.5 & 3 \\
\hline District 6 & 150,356 & 23,919 & 15.9 & - \\
\hline
\end{tabular}




\begin{tabular}{|l|l|l|l|l|}
\hline District 7 & 173,643 & 31,767 & 18.3 & 1 \\
\hline District 8 & 186,179 & 35,235 & 18.9 & 5 \\
\hline District 9 & 186,566 & 44,570 & 23.9 & 9 \\
\hline
\end{tabular}

Source: https://www.comune.milano.it/

Even within the districts with the highest immigration rates, however, the distribution of the centers is not homogeneous. In a wider sense, the farther people go from the city center, the more they can find reception centers. From this perspective, the Milan railway line has a strong territorial and symbolic value, since it describes the boundary of an arch, located at the north-eastern end of the municipality, containing the neighborhoods with the highest concentration of structures, such as the Central Station neighborhood - its attraction for immigrants has been already described above - along with Lambrate, Crescenzago and Viale Padova.

\section{Conclusion}

The case study presented in this paper has shown the complex and multidirectional interaction between institutions acting in the asylum sector.

The research has analyzed in particular whether local actors keep a significant space of action in order to pursue their own agenda and influence the local implementation of national policies.

In Milan the reception policies for asylum seekers and refugees are implemented by the interaction between local institutions, non-governmental organizations and a less structured network of small groups of volunteers. Those parties make up the so-called "Milan model", a system which finds its roots in the social history of the city, but - as put by the local development literature (Dematteis, Governa, 2005) - always produces innovative political and social configurations.

Nevertheless, from a theoretical point of view, it is thus complex to define once and for all whether the interaction between local and national institutions work either in terms of synergy or in terms of competition.

70 In some cases, the local system for Refugees and Asylum seekers reception is led by a form of vertical coordinated interaction between various government levels (Sholten, 2013). In this direction, the cases of "Municipal CAS" and the introduction of the new status of "Transitante" prove how national policies have been re-read from a local perspective.

In other cases, on the contrary, the Milanese policies for the governance of integration are antagonistic to supra-local bodies decisions, attempting to modify or subvert them.

2 In such situations, the Milan Model acts as a humanitarian bulwark in order to face the widespread anti-immigration sentiment (Babels, 2018), through an active involvement of many public and private, local and state actors.

In a political context that has progressively restricted the space for welcoming policies, Milan is challenging the national government on this topic, emerging as a reference point for those who are advocating for an alternative immigration policy: in the last 
three years the city Mayor and some council members have taken position in public demonstrations on this issue ${ }^{20}$.

This model showed some undoubted strengths, such as the capacity to involve a multiplicity of protagonists, the attention and dynamism of the local authorities, the contractual force with central bodies make it one of the positive models, at least within the Italian context.

However, there are some relevant weak points, which sometimes prevent the Milan Model from compensating for the drawbacks of the central authority in terms of integration of refugees and asylum seekers.

Firstly, the room for maneuver of the local policies isn't sufficient to modify the national structure: "there is an obvious mismatch between the role of localities as being the major places of reception and integration of asylum seekers on the one hand, and their limited role in the decision-making process around whether to take in asylum seekers or not, and how (...) they can shape asylum seekers' paths to long-term integration" (Glorious and Doomernik, 2020, p. 2).

Secondly, in some aspects the local governance reproduces the national distortions determined by the "emergency approach", which placed refugees and asylum in "liminal" areas, waiting to be granted the full right of access to goods and services (Sanyal, 2012; Kreichouf, 2018). Therefore, "the state literally takes place in the everyday spaces of the city, which means its exclusions are also decided there" (Young, 2011, p. 542). This is evident from both the local disproportion in the number of CAS and SPRAR guests and the distribution patterns of the reception centers within the urban area which could lead to political tensions between the center and the periphery (in 2016 municipal elections the local government has lost the majority in five of the eight peripheral councils).

More deeply, the concentration of the centers in the peripheral areas of the city seems to indicate that asylum seekers are still considered a sort of externality to be managed instead of right-holders integrated in the social life of the city.

In conclusion, the Milan Model cannot be considered as an ideal typical of local governance (centralist, localist, multi-governance or decoupled), but as the result of a dialectic tension among policies of different levels, which from time to time can lead to conflicts or joint improvements.

\section{BIBLIOGRAPHY}

ACCORINTI M. (2015), « Centri di accoglienza: varietà tipologia e dibattito collegato », Rivista delle Politiche Sociali, 2/3, pp. 179-200.

ANCI, CARITAS ITALIANA, CITTALIA, FONDAZIONE MIGRANTES, SERVIZIO CENTRALE DELLO SPRAR, UNHCR (2017), Rapporto sulla protezione internazionale in Italia 2017, https://www.sprar.it/ wp-content/uploads/2017/11/Rapporto_protezione_internazionale_2017_extralight.pdf, retrieved $2 / 8 / 2019$. 
BABELS (éd.) (2018), Entre accueil et rejet: ce que les villes font aux migrants, Lyon, Le Passager Clandestin.

BADIE B. (1995), La Fin des territoires. Essai sur le désordre international et sur l'utilité sociale du respect, Paris, Fayard.

BADIE B., BRAUMAN R., DECAUX E., DEVIN G. \& WIHTOL DE WENDEN C. (eds.) (2008), Migration: A New Perspective. Building Global Governance, Paris, SciencesPo.

BALDONI E., CALDAROZZI A., GIOVANNETTI M. \& MARCHESINI N. (2018), Atlante Sprar 2017. Rapporto Annuale Sistema di Protezione per Richiedenti Asilo e Rifugiati, Roma, Tipografia Grasso.

BALIBAR E. (2016), Europe: crise et fin?, Lormont, Le Bord de l'eau.

BRENNER N. (2004), New State Spaces. Urban governance and the rescaling of statehood, Oxford University Press.

BROWN L.A., CHUNG S.Y. (2006), "Spatial segregation, segregation indices and the geographical perspective”, Population, Space and Place, 12, pp. 125-143.

CAPONIO T., BORKERT M. (2010), The local dimension of migration policymaking, Amsterdam University Press.

COPPOLA A., « Emergenza siriani, 500 arrivi in 3 giorni: esauriti i posti letto », Corriere della Sera, $4 / 1 / 2015$.

DEMATTEIS G., GOVERNA F. (eds.) (2005), Territorialità, sviluppo locale, sostenibilità: il modello SLoT, Milano, Franco Angeli.

EUROPEAN PARLIAMENT, COUNCIL OF THE EUROPEAN UNION (2013), Regulation (EU) No. 604/2013. EUROPEAN PARLIAMENT, COUNCIL OF THE EUROPEAN UNION (2016), Regulation (EU) No. 2016/399. GLICK SCHILLER N., ÇAĞLAR A. (2009), "Towards a Comparative Theory of Locality in Migration Studies: Migrant Incorporation and City Scale", Journal of Ethnic and Migration Studies, 35, 2, pp. 177-202.

GLORIUS B., DOOMERNIK J (2020), “Introduction”, in GLORIUS B., DOOMERNIK J. (eds.), Geographies of Asylum in Europe and the Role of European Localities, Cham, Springer.

KREICHAUF R. (2018), "From forced migration to forced arrival: the campization of refugee accommodation in European cities", Comparative Migration Studies, 6, 7, pp. 1-22.

MASSEY D.S., DENTON N.A. (1988), “The dimensions of residential segregation”, Social Forces, 67, pp. 281-315.

MUSTERD S., OSTENDORF W. (2013), Urban Segregation and the Welfare State. Inequality and Exclusion in Western Cities, New York, Routledge.

PANIGA M. (2012), Welfare ambrosiano. Storia, cultura e politiche dell'ECA di Milano (1937-1978), Milano, Franco Angeli.

PHILLIPS L. (2013), The Escalating Syrian Refugee Crisis Challenges the International Community's Ability to Respond, https://www.migrationpolicy.org/article/escalating-syrian-refugee-crisis-challengesinternational-communitys-ability-respond\#, retrieved 1/5/2019.

REARDON S., O'SULLIVAN D. (2004), "Measures of spatial segregation”, Sociological Methodology, 34, pp. 121-162.

SANYAL R. (2012), "Refugees and the City. An Urban Discussion", Geography Compass, 6, 11, pp. 633-644. 
SASSEN S. (2001), The Global City: New York, London, Tokyo, Princeton University Press.

SAYAD A. (1999), «Immigration et "pensée d'État” », Actes de la Recherche en Sciences Sociales, 129, pp. 5-14.

SCHNELL I., BAKER DIAB A.A. \& BENENSON I. (2015), “A global index for measuring socio-spatial segregation versus integration”, Applied Geography, 58, pp. 179-188.

SCHOLTEN P. (2013), "Agenda dynamics and the multi-level governance of intractable policy controversies: the case of migrant integration policies in the Netherlands", Policy Sciences, 46, 3, pp. 217-236.

SEMPREBON M., PELACANI G. (2020), "Dispersal and Reception in Northern Italy: Comparing Systems along the Brenner in Route”, in GLORIUS B., DOOMERNIK J. (eds.), Geographies of Asylum in Europe and the Role of European Localities, Cham, Springer.

SMITH D.P. (2012), "The social and economic consequences of housing in multiple occupation (HMO) in UK coastal towns: geographies of segregation", Transactions of the Institute of British Geographers, 37, 3, pp. 461-476.

SWYNGEDOUW E. (2004), “Globalisation or 'glocalisation'? Networks, territories and rescaling”, Cambridge Review of International Affairs, 17, 1, pp. 25-48.

WIHTOL DE WENDEN C. (2017), La question migratoire au XXI ${ }^{e}$ siècle. Migrants, réfugiés et relations internationales, Paris, Presses de SciencesPo.

YOUNG J.E.E. (2011), “'A new politics of the city'. Locating the limit of hospitality and practicing the city-as refuge", Acme, 10, pp. 534-563.

\section{NOTES}

1. The civil war in Syria which began in 2011, escalated in dramatic fashion in 2013, sending more than 1.8 million Syrians fleeing for refuge in neighbouring countries and beyond, "earning the unwelcome distinction of becoming the largest humanitarian emergency in nearly two decades" (Phillips, 2013).

2. The law 132/2018 renames this system SIPROIMI (Sistema di protezione per titolari di protezione internazionale e per i minori stranieri non accompagnati - Protection System for holders of international protection and for unaccompanied minors) and limits the possibility to access to those who have already obtained the international protection.

3. Regulation (EU) No. 604/2013 of the European Parliament and of the Council of 26 June 2013.

4. The so-called "security law" 132/2018 cancels the humanitarian protection.

5. Source: ISTAT (https://www.istat.it/it/files/2018/11/Report_cittadini_non_comunitari.pdf ; http://demo.istat.it/altridati/noncomunitari/index.html); Ministry of Internal Affairs.

6. http://www.unhcr.org/statistics.

7. The distribution takes place according to a system of progressive quotas, taking into consideration regions' number of asylum seekers with respect to the total number of inhabitants and the percentage of access to funding from national funds for social policy. For more details on reception structures see Accorinti (2015) and Semprebon, Pelacani (2020).

8. In April 2011, the Italian Ministry of Interior launched the Emergency North Africa Program, which ended in December 2012.

9. The extraordinary system was consolidated and was finally institutionalized in 2014, on the basis of an understanding among the State, the Regions and local entities (Circolare n. 7418 del 20 giugno 2014). 
10. Source: Camera dei Deputati, https://immigrazione.it/docs/2017/dati-statistici-23gennaio-2017.pdf.

11. Cf. Prefecture of Milan: http://www.prefettura.it/milano/allegati/ Download:Allegato_b_schema_di_convenzione-5732499.htm.

12. For the City of Milan the "Syrian Emergency" began on October 18, 2013. During that year 54,000 refugees $(14,000$ of which were children) passed through the centers set up by the third sector (Corriere della Sera, 4th January 2015).

13. The term Transitante can be translated into English as "person in transit".

14. Source: Municipality of Milan. Data available on the website of the municipality:

http://mediagallery.comune.milano.it/cdm/objects/changeme:85727/datastreams/

dataStream22796539926354324/content?pgpath=/SA_SiteContent/SFOGLIA_NEWS/

Notizie_Primo_Piano/Tutte_notizie/politiche_sociali/migranti_accoglienza_relocation_milano.

15. The temporary reintroduction of internal border controls within the territory of the European Union came into force on 12 April 2016 (Articles 25 and 26 of EU Regulation 2016/399 of the European Parliament and of the Council). It has encouraged the creation of barriers between Italy and its neighboring countries, in particular with France near Ventimiglia, Switzerland near Chiasso and Austria on the Brenner Pass.

16. Sammartini center in 2013 was transformed into a municipal CAS for 70 guests.

17. This most "local" institution, located near Milano Centrale station, is named as CASC (Centro Aiuto Stazione Centrale - Central Station Aid Center). It was created when the evolution of the political framework marked a progressive marginalization of the informal actors once playing a decisive part in facing the "Syrian Emergency".

18. Translation by the authors.

19. Source: Municipality of Milan. Data available on the website of the municipality: http://mediagallery.comune.milano.it/cdm/objects/changeme:85727/datastreams/ dataStream22796539926354324/content?pgpath=/SA_SiteContent/SFOGLIA_NEWS/ Notizie_Primo_Piano/Tutte_notizie/politiche_sociali/migranti_accoglienza_relocation_milano. 20. The municipality of Milan has led major collective events promoting integration, such as "Milan without walls" (20 May 2017) and "People" (2 March 2019).

\section{ABSTRACTS}

The paper deals with the Italian system of second reception for Asylum Seekers and Refugees from 2013 to 2018, specifically focusing on the case of Milan. The paper addresses the subject from a geographical perspective: first, it focuses on the multi-scalar interaction between international community, national governments, local communities and civil society; secondly, it analyzes the spatial dimension of the reception system at the urban scale. The Municipality of Milan has modified the national approach, developing a specific welcoming system (the so-called "Milan model") more open and efficient than the national average. The second axis of our research concerns the socio-spatial segregation of asylum seekers within the urban fabric, showing that even a welcoming system that is usually considered as a positive model still presents some relevant weak points.

L'article traite du système italien de deuxième réception pour les demandeurs d'asile et les réfugiés de 2013 à 2018, en se concentrant spécifiquement sur le cas de Milan. Le document 
aborde le sujet d'un point de vue géographique : premièrement, il met l'accent sur l'interaction multi-scalaire entre la communauté internationale, les gouvernements nationaux, les communautés locales et la société civile; deuxièmement, il analyse la dimension spatiale du système de réception à l'échelle urbaine. La municipalité de Milan a modifié l'approche nationale en développant un système d'accueil spécifique (dit « modèle de Milan ») plus ouvert et efficace que la moyenne nationale. Le deuxième axe de notre recherche concerne la ségrégation sociospatiale des demandeurs d'asile au sein du tissu urbain, montrant que même un système d'accueil généralement considéré comme un modèle positif présente encore importants éléments de faiblesse.

INDEX

Mots-clés: réfugiés, demandeurs d'asile, politiques d'accueil, Milan, Italie

Keywords: refugees, asylum seekers, welcoming policies, Milan, Italy

\section{AUTHORS}

\section{VALERIO BINI}

Università degli Studi di Milano, valerio.bini@unimi.it

GIUSEPPE GAMBAZZA

Università degli Studi di Milano, giuseppe.gambazza@unimi.it 